\title{
IMPLEMENTASI PENINGKATAN KEPROFESIAN BERKELANJUTAN (PKB) DI SMKN 1 SEYEGAN SLEMAN JURUSAN TEKNIK GAMBAR BANGUNAN
}

\author{
Muhammad Nuruzzaman ${ }^{1}$, Sutarto ${ }^{2}$ \\ ${ }^{1,2}$ Pendidikan Teknik Sipil dan Perencanaan, FT, UNY \\ E-mail: mnzaman@uny.ac.id
}

\begin{abstract}
This study aims to: (1) know the perception of teachers of the ADT Department, SMKN 1 Seyegan of procedures and requirements of the CPD imposed by the government, (2) know the effectiveness of the CPD implementation on scientific publication aspect at the ADT Department, SMKN 1 Seyegan, and (3) know the effectiveness of the CPD implementation on innovative work aspect at the ADT Department, SMKN 1 Seyegan. This research was a descriptive research. The study population was all teachers who taught in ADT majors totalling 32 teachers (18 normative teachers, 10 adaptive teachers, and 4 productive teachers) and the whole population became the sample. The data were collected using a questionnaire and through interviews. The data analysis used the quantitative descriptive statistical technique for the quantitative data and the qualitative descriptive technique for the qualitative data. The results were as follows. (1) The perception of the teachers of Department of Architectural Drawing Technique (ADT) of SMKN 1 Seyegan Sleman toward CPD procedure was in a good category $(X=4,96$, good category $=4,5 \leq X<6,75)$. (2) The effectiveness of CPD implementation on scientific publication aspect at the ADT Department of SMKN 1 Seyegan was ineffective category $(12,13 \%)$. (3) The effectiveness of CPD implementation on innovative work aspect at the ADT Department of SMKN 1 Seyegan was ineffective category $(22,26 \%)$.
\end{abstract}

Keywords: implementation, continuing professional development (CPD), architectural drawing technique

\begin{abstract}
ABSTRAK
Kajian ini bertujuan untuk: (1) mengetahui persepsi guru SMKN 1 Seyegan Jurusan TGB terhadap prosedur kenaikan pangkat PKB; (2) mengetahui keefektifan implementasi PKB pada aspek publikasi ilmiah di $S M K N 1$ Seyegan Jurusan TGB, dan (3) mengetahui keefektifan implementasi PKB pada aspek karya inovatif di SMKN 1 Seyegan Jurusan TGB. Kajian ini merupakan Kajian diskriptif. Populasi Kajian adalah seluruh guru yang mengajar di Jurusan TGB, yang berjumlah 32 orang (18 guru normatif, 10 guru adaptif, dan 4 guru produktif) dan keseluruhan populasi dijadikan sampel. Pengumpulan data menggunakan kuesioner dan melalui wawancara. Analisis data menggunakan teknik statistik deskriptif kuantitatif untuk data kuantitatif dan teknik diskriptif kualitatif untuk data kualitatif. Hasil Kajian adalah sebagai berikut. (1) Persepsi guru SMKN 1 Seyegan Sleman Jurusan TGB terhadap prosedur kenaikan pangkat PKB masuk kategori baik (X=4,96, kategori baik=4,5 $\leq X<6,75$ ). (2) Keefektifan implementasi PKB aspek publikasi ilmiah di SMKN 1 Seyegan Jurusan TGB masuk kategori tidak efektif (12,13\%). (3) Keefektifan implementasi PKB aspek karya inovatif di SMKN 1 Seyegan Jurusan TGB masuk kategori tidak efektif $(22,26 \%)$.
\end{abstract}

Kata Kunci: implementasi, peningkatan keprofesian berkelanjutan (PKB), teknik gambar bangunan (TGB)

\section{PENDAHULUAN}

Guru adalah pendidik profesional dengan tugas utama mendidik, mengajar, membimbing, mengarahkan, melatih, menilai, dan mengevaluasi peserta didik pada pendidikan anak usia dini jalur pendidikan formal, pendidikan dasar dan pendidikan menengah. Kedudukan guru sebagai tenaga profesional sebagaimana dimaksud dalam Pasal 2 ayat (1) berfungsi untuk meningkatkan martabat dan peran guru sebagai agen pembelajaran berfungsi untuk meningkatkan mutu pendidikan nasional (UU RI No 14 Tahun 
2005). Tuntutan kepada guru sebagai tenaga pendidik profesional memiliki arti ganda, yaitu pertama guru harus konsisten dalam meningkatkan kemampuan diri dan yang kedua ialah mendidik, mengajar, membimbing, mengarahkan, melatih, menilai, dan mengevaluasi peserta didik dalam rangka untuk meningkatkan mutu pendidikan nasional.

Upaya pemerintah untuk meningkatkan kompetensi guru ialah dengan cara memberikan pelatihan, diklat, seminar hingga membuat kebijakan/perturan yang dikhususkan untuk guru. Kebijakan/ peraturan tersebut beraneka ragam, ada yang mengharuskan guru harus memiliki pendidikan minimal sarjana/diploma IV (UU RI No 14 Tahun 2005). Peraturan tersebut dituangkan dalam Peraturan Menteri Negara dan Pendayagunaan Aparatur Negara dan Reformasi Birokrasi Nomor 16 Tahun 2009 tentang Jabatan Fungsional Guru dan Angka Kreditnya (Peraturan Menpan RB No. 16 Tahun 2009). Pada peraturan tersebut dijabarkan apa saja kewajiban-kewajiban yang harus dilakukan oleh guru dan bagaimana perhitungan angka kredit yang digunakan sebagai syarat untuk pengajuan kenaikan pangkat.

Realitas kondisi guru yang berstatus Pegawai Negeri Sipil (PNS) di Provinsi Jawa Tengah di semua jenjang dan jenis pendidikan menunjukkan indikasi yang memprihatinkan. Dikarenakan hampir 60\% guru PNS yang berada pada jenjang kepangkatan IVa tidak dapat naik pangkat ke IVb. Khusus guru Sekolah Menengah guru yang telah menduduki pangkat golongan IVa mencapai 50,88\%, sedangkan guru yang mampu naik pangkat ke IV $\mathrm{b}$ dan seterusnya hanya sebesar $0,5 \%$ dari jumlah total (Yunanto, 2007). Realita ini terjadi dikarenakan ketidakmampuan guru untuk memenuhi standar minimal yang dipersyaratkan oleh pemerintah dalam peraturan PKB. Terutama syarat untuk naik pangkat dari golongan IVa ke golongan IVb. Hal tersebut menjadi bukti, bahwa komitmen dan kemampuan guru untuk meningkatkan kualitas KBM masih sangat rendah. Pemicunya adalah sistem PAK bagi guru PNS tidak memberikan ruang bagi guru untuk berlatih dan mengasah kemampuan pengembangan profesi (Yunanto, 2007).

Berdasarkan studi awal berupa observasi di lapangan dan wawancara terhadap beberapa guru SMK Negeri 1 Sedayu, Bantul dan SMK Negeri 2 Pengasih, Kulon Progo, menunjukkan bahwa selama ini, model pengembangan keprofesian guru SMK masih bersifat parsial, belum menunjukkan keberlanjutan, dan belum memperlihatkan keoptimalan (Soeharto dkk, 2013). Setelah dilaksanakan observasi di SMKN 1 Seyegan didapatkan hasil sebagai berikut. Dari 64 Guru PNS yang mengajar di sekolah tersebut, terdapat 3 Guru PNS yang berada pada golongan IIIa, 7 Guru PNS yang berada pada golongan IIIb, 10 Guru PNS yang berada pada golongan IIIc, 12 Guru PNS yang berada pada golongan IIId, dan 32 Guru PNS yang berada pada golongan IVa. Data tersebut mengindikasikan bahwa setegah dari jumlah guru yang ada di SMKN 1 Seyegan mengalami kendala untuk mengajukan kenaikan pangkat pada golongan IVb. Bahkan yang lebih memprihatinkan, tidak ada satupun guru di SMK tersebut yang berada pada golongan IVb ke atas (sampai dengan bulan juni 2017).

Penulisan karya tulis ilmiah memang menjadi momok tersendiri bagi guru dalam rangka syarat untuk pengajuan kenaikan pangkat. Implementasi di lapangan ditemui guru yang sudah berhasil menuliskan ide dan gagasanya dalam bentuk karya tulis ilmiah akan tetapi karya tulis tersebut tidak dinilai oleh tim penilai karya tulis. Tentunya hal tersebut membuat guru semakin kesulitan dalam rangka pemenuhan angka kredit untuk pengajuan kenaikan pangkat. Dikarenakan temuan beberapa masalah di atas, akan dikupas secara lebih mendalam tentang implementasi PKB yang ada di SMKN 1 Seyegan. Setelah diketahui bagaimana implementasi PKB di SMKN 1 Seyegan tentu akan didapati berbagai masalah yang dimungkinkan sama dengan 
masalah masalah yang ditemui di beberapa sekolah di atas maupun masalah baru yang hanya ada di SMK seyegan tersebut. Langkah selanjutnya adalah mencari strategi untuk mengatasi berbagai masalah yang ditemui di SMKN 1 Seyegan.

Kegunaan dari kajian ini diharapkan dapat memberikan sumbangan pemikiran yang berkaitan dengan peningkatan keprofesian berkelanjutan (PKB). Kepala sekolah dapat mengetahui tingkat pemahaman guru, tingkat keaktifan guru dan kendala yang dialami oleh guru tentang PKB di SMK yang dipimpin, kemudian kepala sekolah dapat mengambil kebijakan yang tepat untuk mengatasi permasalahan-permasalahan yang terjadi, sehingga untuk kedepan proses PKB bagi pendidik dan tenaga kependidikan dapat berjalan lebih maksimal.

\section{Profesi Guru}

Guru adalah pendidik profesional dengan tugas utama mendidik, mengajar, membimbing, mengarahkan, melatih, menilai dan mengevaluasi peserta didik pada pendidikan anak usia dini jalur pendidikan formal, pendidikan dasar dan pendidikan menengah (UU RI No 14 Tahun 2005).Guru merupakan suatu keahlian atau kemahiran dalam bidang pendidikan yang meliputi proses perencanaan, pelaksanaan dan evaluasi pembelajaran dimana pembelajaran yang diberikan merupakan pendidikan yang berkualitas sehingga melahirkan generasi penerus yang unggul dan berkepribadian demi kemajuan bangsa.

\section{Pengembangan Keprofesian Berkelanjutan (PKB)}

Pengembangan keprofesian berkelanjutan (PKB) adalah pengembangan kompetensi guru yang dilaksanakan sesuai dengan kebutuhan, bertahap, berkelanjutan untuk meningkatkan profesionalitasnya. Hal tersebut dilatarbelakangi adanya konsep bahwa salah satu aspek yang memiliki peran yang sangat strategis dalam usaha peningkatan proses pembelajaran dan mutu peserta didik adalah guru (Peraturan Menpan RB No. 16 Tahun 2009). PKB merupakan suatu kegiatan yang perlu untuk dilakukan karena memiliki manfaat mengefektifkan kegiatan praktik dan untuk mengembangkan diri. Dengan kata lain PKB merupakan kegiatan yang memiliki manfaat untuk mengembangkan diri baik secara langsung maupun tidak langsung dan entah sesuai maupun tidak sesuai dengan profesi yang ditekuni (Schostak dkk, 2010).

PKB merupakan salah satu komponen pada unsur utama yang kegiatanya diberikan angka kredit. Sedangkan unsur utama yang lainya sebagaimana dijelaskan pada Peraturan Menpan RB No. 16 Tahun 2009 bab V pasal 11, adalah (1) Pendidikan; (2) Pembelajaran; (3) Penunjang. Sedangkan unsur kegiatan pengembangan keprofesian berkelanjutan (PKB) terdiri dari tiga macam, yaitu kami sajikan pada Tabel berikut ini.

Tabel 1. Unsur Kegiatan Pengembangan Keprofesionalan Berkelanjutan (PKB)

\begin{tabular}{llll}
\hline $\begin{array}{c}\text { Macam Pengembangan } \\
\text { Keprofesian Berkelanjutan } \\
\text { (PKB) }\end{array}$ & & \multicolumn{2}{c}{ Yang meliputi } \\
\hline 1 & Pengembangan Diri & 1) & Mengikuti diklat fungsional \\
& & 2) & Melaksanakan kegiatan kolektif guru \\
\hline 2 & Publikasi Ilmiah & a) & Membuat publikasi ilmiah atas hasil Kajian \\
& & b) & Membuat publikasi buku \\
\hline 3 & Karya Inovatif & a) & Menemukan teknologi tetap guna \\
& & b) & Menemukan/menciptakan karya seni \\
& c) & Membuat/memofikasi alat pelajaran \\
& d) & Mengikuti pengembangan penyusunan standar, pedoman, soal dan \\
& & sejenisnya \\
\hline
\end{tabular}




\section{METODE}

Kajian ini merupakan kajian diskriptif. Metode yang digunakan dalam kajian ini adalah diskriptif kuantitatif dan kualitatif untuk menggambarkan subjek yang diteliti dengan jelas. Penelitian bertempat di Jurusan Teknik Gambar Bangunan (TGB) SMKN 1 Seyegan. Waktu penelitian dimulai pada bulan april sampai dengan bulan Juli tahun 2017.

Populasi yang digunakan adalah seluruh guru yang mengajar di Jurusan Teknik Gambar Bangunan (TGB) SMKN 1 Seyegan yang berjumlah 32 guru terdiri dari 18 guru normatif, 10 guru adaptif dan 4 guru produktif. Teknik pengumpulan data digunakan berupa angket dan dilengkapi dengan wawancara. Angket yang digunakan merupakan angket tertutup dan angket terbuka. Angket tertutup bagian pertama digunakan mengukur persepsi guru tentang PKB. Agket menggunakan Skala Likert (skala 4). Angket tertutup digunakanan untuk mengukur keefektifan implementasi PKB guru. Angket tertutup menggunakan Skala Guttman.

$\begin{array}{crr}\text { Validitas } & \text { intrumen menggunakan } \\ \text { metode } & \text { expert } & \text { judgement. }\end{array}$ instrumen menggunakan Cronba Alpha untuk angket tertutup bagian pertama dan rumus Spearman-Browman untuk angket tertutup bagian kedua. Setelah dilakukan uji reliabilitas, instrumen yang menggunakan Skala Likert memiliki nilai Cronbach Alpha adalah 0,627.
Maka dapat disimpulkan instrumen reliabel sebesar 0.5262 dapat disimpulkan instrumen reliabel. Teknik analisis data disesuaikan dengan karakteristik dari data, untuk data yang bersifat kuantitatif dianalisis dengan menggunakan teknik statistik deskriptif kuantitatif. Untuk data yang bersifat kualitatif dianalisis dengan analisis deskriptif kualitatif.

\section{HASIL DAN PEMBAHASAN}

Deskripsi hasil Kajian implementasi PKB di SMKN 1 Seyegan Sleman jurusan Teknik Gambar Bangunan (TGB) disajikan dalam grafik persentase dari setiap butir indikator Peningkatan Keprofesian Berkelanjutan yang diteliti pada data kuantitatif. Pada data kualitatif, disajikan dalam bentuk uraian dan tabel berdasarkan data yang diperoleh.

Persepsi Guru terhadap Prosedur Kenaikan Pangkat PKB

Prosedur kenaikan pangkat PKB yang selama ini telah dipahami oleh guru di SMKN 1 Seyegan jurusan Teknik Gambar Bangunan diungkap melalui data kuantitatif dengan kuesioner didukung dengan data kualitatif melalui wawancara dengan guru di SMKN 1 Seyegan Jurusan Teknik Gambar Bangunan, sebagaimana dituangkan dalam gambar 1 diagram batang Distribusi Frekuensi Data Persepsi Guru Terhadap Prosedur Kenaikan Pangkat PKB.

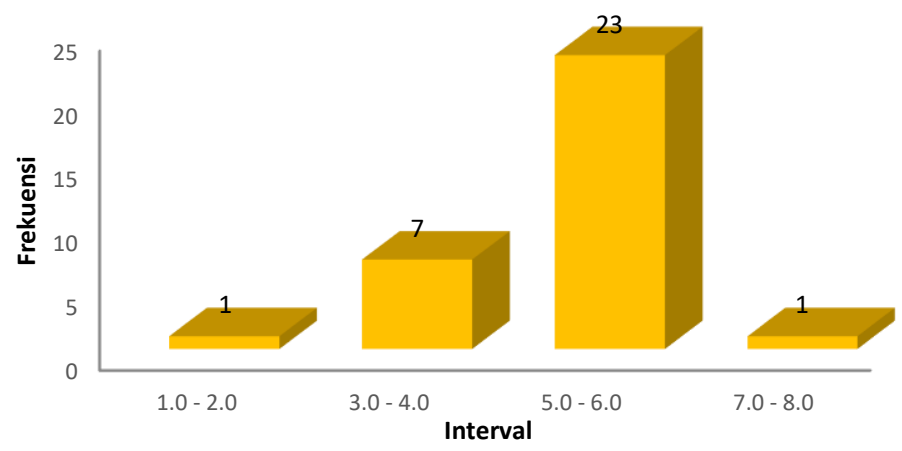

Gambar 1. Diagram Batang Distribusi Frekuensi Data Persepsi Guru Terhadap Prosedur Kenaikan Pangkat PKB 
Berdasarkan data angket tertutup bagian pertama dapat disimpulkan bahwa rata-rata persepsi guru SMKN 1 Seyegan terhadap implementasi PKB masuk kategori baik $(X=4,96$, kategori baik= 4,5 $\leq X<6,75)$. Selanjutnya data hasil wawancara disajikan berikut ini.

Hasil dari wawancara menyebutkan bahwa persespsi sebagian besar guru $(55,21 \%)$ sudah baik tentang prosedur kenaikan pangkat PKB. Akan tetapi yang disayangkan ialah, sebagian besar guru hanya sampai pada tahap mengakui bahwa PKB tersebut baik bagi guru akan tetapi belum sampai pada tahap mengaplikasikan PKB untuk mengajukan kenaikan pangkat. Penyebab utama yang melatarbelakangi ialah kurangnya fasilitasi PKB dari sekolah untuk guru-guru yang ingin mengajukan kenaikan pangkat. Dalam hal ini guru merasa kurangnya pembinaan dari sekolah dan minimnya fasilitas yang diberikan kepada guru untuk melaksanakan PKB.

Penyebab selanjutnya ialah kurangnya motivasi guru untuk belajar mandiri agar mampu melengkapi persyaratan-persyaratan yang dibutuhkan dalam proses pengajuan kenaikan pangkat. Dengan kata lain banyak persyaratan yang tidak gampang dikuasai dan menuntut guru untuk belajar lebih banyak. Diantaranya guru diharuskan mampu menguasai metodologi PTK apabila ingin melaksanakan PTK di sekolah. Guru diharuskan mampu menulis jurnal dengan standar penulisan yang sesuai dengan persyaratan jurnal tertentu apabila ingin mempublikasikan hasil kajian ke dalam jurnal tersebut. Kemudian guru juga diwajibkan mampu berpikir kreatif dan inovatif apabila ingin menemukan/ menciptakan karya teknologi tepat guna yang bermanfaat bagi lingkungan sekitarnya. Hal tersebut menjadi salah satu hambatan bagi guru dalam melaksanakan prosedur kenaikan pangkat yang sudah dipahami.

Keefektifan Implementasi PKB pada Aspek Publikasi Ilmiah/Presentasi Pada Forum Ilmiah
Berdasarkan hasil analisa diperoleh kesimpulan bahwa pengkategorian keefektifan guru SMK Seyegan Jurusan TGB dalam mengimplementasikan PKB sub aspek kegiatan presentasi pada forum ilmiah masuk kategori tidak efektif $(13,28 \%)$. Hal ini menunjukkan bahwa sebanyak $86,72 \%$ guru belum melaksanakan/ mengimplementasikan sub aspek kegiatan presentasi pada forum ilmiah. Dengan kata lain dari total 32 guru yang mengajar di SMKN 1 Seyegan Jurusan TGB, hanya 4 hingga 5 guru saja yang telah mengimplementasikan PKB sub aspek kegiatan presentasi pada forum ilmiah. Sebagian besar guru menjelaskan bahwa saat akan melaksanakan presentasi pada forum ilmiah tentu harus ada bahan yang akan dipresentasikan. Bahan presentasi dapat berupa hasil kajian, gagasan ilmiah, prasaran ilmiah dll. Proses menyusun bahan inilah yang menjadi kendala terbesarnya, yaitu terbatasnya waktu yang dimiliki guru untuk menulis dan meneliti. Selanjutnya kurangnya informasi guru terhadap cara/teknik menemukan masalah sehingga guru merasa kesulitan untuk menulis ide atau gagasan untuk dipresentasikan pada forum ilmiah.

Berdasarkan hitungan diperoleh kesimpulan bahwa pengkategorian keefektifan guru SMK Seyegan Jurusan TGB dalam mengimplementasikan PKB aspek kegiatan publikasi ilmiah sub aspek publikasi hasil Kajian/gagasan ilmiah masuk kategori tidak efektif $(6,25 \%)$. Hal ini menunjukkan bahwa sebanyak $93,75 \%$ guru belum melaksanakan/ mengimplementasikan sub aspek kegiatan presentasi pada forum ilmiah. Dengan kata lain dari total 32 guru yang mengajar di SMKN 1 Seyegan Jurusan TGB, hanya 2 guru saja yang telah mengimplementasikan PKB aspek publikasi ilmiah sub aspek publikasi hasil Kajian/gagasan ilmiah. Sebagian besar guru menjelaskan bahwa saat akan melaksanakan publikasi ilmiah berupa hasil Kajian/gagasan ilmiah, tentu harus ada hasil Kajian/gagasan yang akan dipublikasikan. 
Publikasi Buku Teks Pelajaran, Pengayaan dan atau Pedoman Guru

Berdasarkan hitungan diperoleh kesimpulan bahwa pengkategorian keefektifan guru SMK Seyegan Jurusan TGB dalam mengimplementasikan PKB aspek kegiatan publikasi ilmiah sub aspek Publikasi Buku Teks Pelajaran, Buku Pengayaan dan atau Buku Pedoman Guru masuk kategori tidak efektif $(17,7 \%)$. Hal ini menunjukkan bahwa sebanyak $82,3 \%$ guru belum melaksanakan/ mengimplementasikan sub aspek publikasi hasil Kajian/gagasan ilmiah. Dengan kata lain dari total 32 guru yang mengajar di SMKN 1 Seyegan Jurusan TGB, hanya 5 guru saja yang telah mengimplementasikan PKB aspek publikasi ilmiah sub aspek publikasi hasil Kajian/gagasan ilmiah. Sebagian besar guru menjelaskan bahwa saat akan publikasi buku teks pelajaran, buku pengayaan dan atau buku pedoman guru tentu harus ada hasil karya yang akan dipublikasikan. Hasil karya tersebut dapat berupa buku teks pelajaran, buku pengayaan dan atau buku pedoman guru.

Keefektifan Implementasi PKB pada Aspek Karya Inovatif di SMKN 1 Seyegan Jurusan TGB

Perancangan/Penemuan Teknologi Tepat Guna (Karya Sains/Teknologi)

Berdasarkan hitungan diperoleh kesimpulan bahwa pengkategorian keefektifan guru SMK Seyegan Jurusan TGB dalam mengimplementasikan PKB aspek Karya Inovatif sub aspek merancang/menemukan teknologi tepat guna (karya sains/teknologi) masuk kategori tidak efektif $(3,33 \%)$. Hal ini menunjukkan bahwa sebanyak 96,67\% guru belum melaksanakan/ mengimplementasikan sub aspek kegiatan merancang/menemukan teknologi tepat guna (karya sains/teknologi). Dengan kata lain dari total 32 guru yang mengajar di SMKN 1 Seyegan Jurusan TGB, hanya 1 guru saja yang telah mengimplementasikan PKB aspek Karya Inovatif sub aspek merancang/menemukan teknologi tepat guna (karya sains/teknologi).
Kegiatan merancang/menemukan teknologi dapat membantu meningkatkan kualitas pembelajaran di kelas, akan tetapi proses untuk dapat merancang/menemukan tesebut tentu tidaklah mudah. Beberapa guru berpendapat bahwa mereka belum memahami cara untuk merancang/ menemukan suatu teknologi. Apabila ide atau gagasan rancangan teknologi telah diperoleh maka biaya untuk proses pembuatanya juga mengalami kendala.

\section{Penemuan/Penciptaan Karya Seni}

Berdasarkan hitungan diperoleh kesimpulan bahwa pengkategorian keefektifan guru SMK Seyegan Jurusan TGB dalam mengimplementasikan PKB aspek Karya Inovatif sub aspek menemukan/menciptakan karya seni masuk kategori tidak efektif $(1,39 \%)$. Hal ini menunjukkan bahwa sebanyak $98,61 \%$ guru belum melaksanakan/ mengimplementasikan sub aspek kegiatan menemukan/ menciptakan karya seni. Dengan kata lain dari total 32 guru yang mengajar di SMKN 1 Seyegan Jurusan TGB, hanya 1 guru saja yang telah mengimplementasikan PKB aspek Karya Inovatif sub aspek menemukan/ menciptakan karya seni. Sebagian besar guru menjelaskan bahwa yang seharusnya melaksanakan menemukan/menciptakan karya seni itu ialah guru yang mengajar pada bidang seni. Untuk guru yang mengajar pada bidang lainya tentu akan sangat jarang untuk melaksanakan sub aspek tersebut.

Pembuatan/ Pemodifikasian Alat Pelajaran/ Peraga/ Praktikum

Berdasarkan hitungan diperoleh kesimpulan bahwa pengkategorian keefektifan guru SMK Seyegan Jurusan TGB dalam mengimplementasikan PKB aspek Karya Inovatif sub aspek membuat/memodifikasi alat pelajaran/ peraga/praktikum masuk kategori tidak efektif $(6,04 \%)$. Hal ini menunjukkan bahwa sebanyak 93,96\% guru belum melaksanakan/ mengimplementasikan sub aspek kegiatan membuat/memodifikasi alat pelajaran/ peraga/praktikum. Dengan kata lain dari total 32 guru yang mengajar di SMKN 1 
Seyegan Jurusan TGB, hanya 2 guru saja yang telah mengimplementasikan PKB aspek Karya Inovatif sub aspek membuat/memodifikasi alat pelajaran/ peraga/praktikum. Sebagian besar guru menjelaskan bahwa membuat/ memodifikasi alat pelajaran/ peraga/praktikum belum dapat dilakukan karena terbatasnya waktu yang dimiliki. Waktu yang dibutuhkan untuk mengajar dan mempersiapkan administrasi pembelajaran sudah sangat banyak, belum lagi waktu untuk bersosial dengan masyarakat, sehingga waktu untuk kegiatan membuat/memodifikasi alat pelajaran/ perga/ praktikum belum ada.

Partisipasi dalam Penyusunan Standar/ Pedoman Soal/Sejenisnya

Berdasarkan hitungan diperoleh kesimpulan bahwa pengkategorian keefektifan guru SMK Seyegan Jurusan TGB dalam mengimplementasikan PKB aspek Karya Inovatif sub aspek mengikuti penyusunan standar/pedoman soal/ sejensinya masuk kategori tidak efektif $(2,78 \%)$. Hal ini menunjukkan bahwa sebanyak $97,22 \%$ guru belum melaksanakan/ mengimplementasikan sub aspek kegiatan mengikuti penyusunan standar/pedoman soal/sejensinya. Dengan kata lain dari total 32 guru yang mengajar di SMKN
1 Seyegan Jurusan TGB, hanya 1 guru saja yang telah mengimplementasikan PKB aspek Karya Inovatif sub aspek mengikuti penyusunan standar/pedoman soal/sejensinya. Sebagian besar guru menjelaskan bahwa tidak semua diberi kesempatan mengikuti penyusunan standar/pedoman soal/ sejensinya. Karena hal tersebut disesuaikan dengan mata pelajaran dari soal apa yang akan di susun. Jika yang akan disusun adalah standar/pedoman soal matematika tentu hanya guru matematika yang akan dikirim, bukan guru fisika ataupun kimia. Itupun tidak seluruh guru matematika dikirim. Mungkin hanya 1 atau 2 guru yang dikirim dari 5 atau 6 guru matematika untuk mengikuti penyusunan standar/pedoman soal/sejensinya. Selanjutnya guru yang dikirim biasanya ialah guru yang sudah berpengalaman dan memiliki rekam jejak yang baik dan ramah dengan teknologi.

\section{PEMBAHASAN}

Setelah dilaksanakan Kajian kepada 32 responden guru yang mengajar di TGB, didapatkan temuan yang akan disajikan pada Tabel berikut ini

Tabel 2. Waktu Jenjang Kepangkatan Guru SMKN 1 Seyegan Jurusan TGB

\begin{tabular}{cccc}
\hline No & Jenjang & Jumlah Guru & Rata-Rata \\
\hline 1 & IV a & 12 & 9,2 \\
\hline 2 & III d & 3 & 4,7 \\
\hline 3 & III c & 4 & 4,8 \\
\hline 4 & III b & 8 & 4,0 \\
\hline 5 & III a & 3 & 3,8 \\
\hline
\end{tabular}

Berdasarkan hasil kajian di atas, diketahui jika waktu guru berada pada jenjang kepangkatan tertentu secara umum dapat disimpulkan bahwa semakin tinggi jenjang kepangkatanya akan semakin lama pula waktu yang dibutuhkan untuk dapat naik pada jenjang berikutnya. Tercatat 7 dari 32 guru memiliki waktu berada pada jenjang kepangkatan terakhir selama lebih dari 10 tahun dan waktu kedepan dimungkinkan waktu 10 tahun tersebut masih akan terus bertambah. Apabila dipresentasekan, lebih dari $20 \%$ guru dari 32 responden guru memiliki waktu pada jenjang kepangkatan terakhir yang cukup panjang yaitu lebih dari 10 tahun. Bahkan ada yang mencapai pada waktu 15 tahun dengan berada pada jenjang kepangkatan yang sama. Tentu dengan adanya peristiwa tersebut perlu di cari apa akar masalahnya dan kemudian bersama-sama untuk dicarikan solusi penyelesaiannya. 
Persepsi Guru SMKN 1 Seyegan Jurusan TGB terhadap Prosedur dan Persyaratan PKB

Berdasarkan deskripsi hasil Kajian diperoleh hasil bahwa rata-rata persepsi guru SMKN 1 Seyegan terhadap prosedur dan persyaratan $\mathrm{PKB}$ masuk kategori baik ( $\mathrm{X}=$ 4,96, kategori baik $=4,5 \leq X<6,75)$, dengan persentase persepsi guru sebesar 55,21\%. Sedangkan guru yang mengajar di SMKN 1 Seyegan Jurusan TGB terdiri dari guru adaptif, normatif dan produktif. Maka perlu dibahas lebih dalam mengenai masing-masing kelompok guru tersebut tentang persepsi mereka terhadap prosedur dan persyaratan pengajuan kenaikan pangkat. Berdasarkan Gambar 2, diperoleh hasil bahwa persepsi ratarata guru produktif lebih unggul dibandingkan guru normatif dan adaptif. Hal ini dikarenakan 4 guru produktif tersebut, sering menjalin komunikasi dengan teman sejawat yang mengajar di sekolah lain tentang kebijakan PKB. Hasil komunikasi tersebut menyatakan bahwa kebijakan PKB sangat baik untuk kemajuan pendidik, oleh karena itulah mereka juga menyatakan bahwa PKB sangat baik bagi pendidik. Hal ini berarti bahwa PKB dapat menjadikan guru lebih efektif, kreatif, termotivasi dan meningkatkan kualitas diri (Walter \& Briggs, 2012). Sebagaimana dalam gambar grafik perbandingan nilai rata-rata persepsi guru tentang prosedur dan persyaratan pkb dengan kelompok guru (normatif, adaptif dan produktif) (gambar 2).



Gambar 2. Grafik Perbandingan Nilai Rata-Rata Persepsi Guru tentang Prosedur dan Persyaratan PKB dengan Kelompok Guru (Normatif, Adaptif Dan Produktif)

Berdasarkan grafik di atas sebanyak dua dari empat guru produktif yang mengajar di TGB adalah guru yang rajin dan bersemangat dalam melanjutkan pendidikan (S2). Oleh karena itulah persepsi kedua guru muda tersebut menyatakan sangat baik. Satu dari dua guru produktif senior juga berpendapat demikian, yaitu sangat baik.

Keefektifan Implementasi PKB Pada Aspek Publikasi Ilmiah di SMKN 1 Seyegan Jurusan TGB

Berdasarkan deskripsi hasil Kajian diperoleh hasil bahwa keefektifan implementasi PKB pada aspek publikasi ilmiah sub aspek publikasi hasil kajian/gagasan ilmiah adalah 6,25\% (tidak efektif). Dilanjutkan keefektifan implementasi PKB pada aspek publikasi ilmiah sub aspek publikasi buku teks pelajaran, buku pengayaan, dan atau buku pedoman guru adalah 17,71\% (tidak efektif). Adapun nilai keefektifan aspek publikasi ilmiah guru di SMKN 1 Seyegan adalah $12,13 \%$ (tidak efektif).Nilai keefektifan aspek publikasi ilmiah akan dijabarkan lebih lanjut berdasarkan kelompok guru (normatif, adaptif dan produktif). Jumlah guru adaptif, normatif dan produktif yang mengajar di SMKN 1 Seyegan Jurusan TGB tidak sama. Maka penyajian data publikasi ilmiah berdasarkan nilai rata-ratanya. Berikut disajikan grafik perbandingan antara rata-rata nilai implementasi PKB aspek publikasi ilmiah dengan kelompok guru (normatif, adaptif dan produktif) 


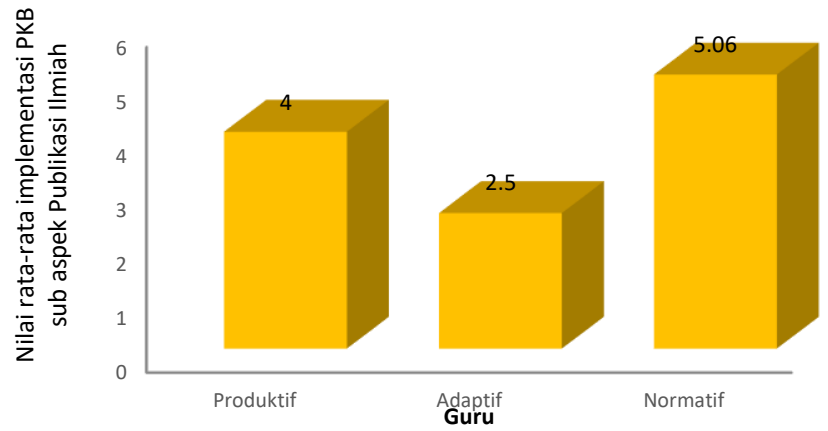

Gambar 3. Grafik Perbandingan Nilai Rata-Rata Implementasi PKB Aspek Publikasi Ilmiah dengan Kelompok Guru (Normatif, Adaptif dan Produktif)

Bedasarkan grafik tersebut nilai implementasi PKB guru aspek publikasi ilmiah pada guru normatif lebih tinggi dibandingkan guru produktif dan adaptif. Hal tersebut dikarenakan banyak guru normatif yang mencoba menulis karya tulis ilmiah maupun menulis buku pelajaran. Akan tetapi kebanyakan dari mereka tidak mampu mempublikasikannya dikarenakan beberapa hal. Ada yang belum mengetahui bagaimana cara untuk mempublikasikan dan ada yang memang tujuan menulis adalah untuk berlatih. Pada aspek publikasi ilmiah guru produktif lebih unggul dibandingkan dengan guru adaptif. Hal tersebut dikarenakan terdapat guru produktif yang membuat modul dan buku mata pelajaran. Karena jumlah guru produktif relatif sedikit dibandingkan guru adaptif maka rata-rata nilai publikasi ilmiah guru produktif cenderung lebih besar. Guru merasa keberatan apabila disamping mengajar yang menjadi tugas utamanya lalu guru diwajibkan untuk meneliti. Hal tersebut disebabkan oleh banyak hal (pada bab deskripsi hasil kajian) seperti kurangnya waktu untuk melaksanakan kajian, belum paham metodologi kajian, susah untuk menentukan judul kajian dsb.

Tuntutan kepada guru agar hasil kajian yang dibuat oleh guru untuk dipublikasikan baik melalui media buku, jurnal dan sebagainya dirasa sangat memberatkan. Hal ini sangat wajar dikarenakan untuk membuat suatu kajian saja guru sudah merasa sangat keberatan apalagi diminta untuk mempublikasikannya. Dengan kata lain guru diminta untuk bersaing dengan guru lainya dalam hal kualitas kajian (mulai dari pemilihan tema kajian, metode kajian, hasil kajian dsb), karena baik jurnal maupun buku dalam menerbitkan suatu karya, tentu melalui seleksi dan pemilihan yang ketat yang berdasarkan kualitas dari karya itu sendiri.

Terdapatan beberapa penyebab banyak guru yang tidak membuat karya ilmiah untuk dipublikasikan. Pertama peraturan sebelum PKB diberlakukan tidak pernah ada persyaratan membuat karya ilmiah dan publikasi ilmiah untuk persyaratan naik pangkat sehingga mereka merasa belum bisa membuat karyakarya tersebut. Alasan yang kedua ialah banyaknya kegiatan yang harus dilakukan di luar tugasnya sebagai guru, seperti kegiatan kemasyarakatan (pertemuan RT/RW, PKK, pengajian, kepanitiaan masjid dan sebagainya), kegiatan olahraga (senam, badminton, renang), kegiatan kesenian (karawitan,salawatan), kegiatan sosial (menghadiri acara arisan, menghadiri acara pernikahan, menjenguk keluarga/teman yang sakit dan sebagainya), hingga kegiatan pribadi (mengasuh cucu, mengasuh hewan peliharaan dan sebagainya). Hal yang menarik adalah alasan yang ketiga yaitu kebanyakan guru pada jenjang ini sudah merasa tidak sanggup lagi untuk naik pangkat dan tidak ingin naik pangkat lagi atau dengan kata lain guru-guru tersebut sudah pasrah dengan pangkat yang diperoleh saat ini. Kebanyakan dari guru-guru tersebut memberikan alasan karena anak-anak yang dimiliki sudah selesai sekolahnya dan sudah bekerja, beberapa ada yang sudah menikah 
bahkan memiliki anak sehingga tidak ada lagi target/keinginan yang harus dikejar. Karena pendapatan yang saat ini di dapat sudah lebih dari cukup.

Hal ini senada dengan pelaksanaan PKB di SMK Otomotif di Purworejo, jika ditinjau dari publikasi ilmiah masih tergolong rendah. Hal tersebut dikarenakan guru dalam melaksanakan publikasi ilmiah hanya berdasarkan tujuan pragmatis jangka pendek, yaitu untuk tujuan kenaikan pangkat semata. Kemudian ukuran kemanfaatan dari publikasi ilmiah belum berdasarkan pada peningkatan kompetensi dan prestasi akan tetapi diukur berdasarkan kompensasi yang didapatkan (Susanto, 2016). Kurang menyadari akan pentingnya sebuah karya tulis ilmiah, terbatasnya waktu, kuranya bimbingan dan sosialisasi penyusunan karya tulis ilmiah kurangnya kesadaran dan motivasi membuat karya tulis dan memerlukan biaya tambahan bila ingin mengikuti pelatihan (Syakbaniyah, 2017).

Keefektifan Implementasi PKB Pada Aspek Karya Inovatif Di SMKN 1 Seyegan Jurusan TGB

Berdasarkan deskripsi hasil Kajian diperoleh hasil bahwa keefektifan implementasi PKB pada aspek karya inovatif sub aspek merancang/menemukan teknologi tepat guna adalah 3,33\% (tidak efektif). Dilanjutkan keefektifan implementasi PKB pada aspek karya inovatif sub aspek menemukan/ menciptakan karya seni adalah 1,39\% (tidak efektif). Angka keefektifan implementasi PKB pada aspek karya inovatif sub aspek membuat/memodifikasi alat peraga/ pelajaran/ praktikum adalah $6,04 \%$ (tidak efektif). Dilanjutkan keefektifan implementasi PKB pada aspek karya inovatif sub aspek penyusunan standar, pedoman soal dan sejenisnya adalah 2,78\% (tidak efektif). Adapun nilai keefektifan aspek karya inovatif guru di SMKN 1 Seyegan adalah 22,26 \% (tidak efektif).

Nilai keefektifan aspek karya inovatif akan dijabarkan lebih lanjut berdasarkan kelompok guru (normatif, adaptif dan produktif). Jumlah guru adaptif, normatif dan produktif yang mengajar di SMKN 1 Seyegan Jurusan TGB tidak sama. Maka penyajian data publikasi ilmiah berdasarkan nilai rata-ratanya. Berikut disajikan grafik perbandingan antara rata-rata nilai implementasi PKB aspek karya inovatif dengan kelompok guru (normatif, adaptif dan produktif). Bedasarkan Gambar 4 inovatif pada guru produktif lebih tinggi dibandingkan guru normatif dan adaptif, Hal ini dikarenakan terdapat guru produktif yang mengikuti kegiatan penyusunan standar/ pedoman soal. Selain itu kegiatan memodifikasi alat peraga juga sering dilakukan oleh guru produktif. Apabila tidak dilakukan tentu akan mengalami kesulitan dalam praktik karena keterbatasan bahan praktik. sebagaimana dapat dilihat pada gambar grafik dibawah ini.

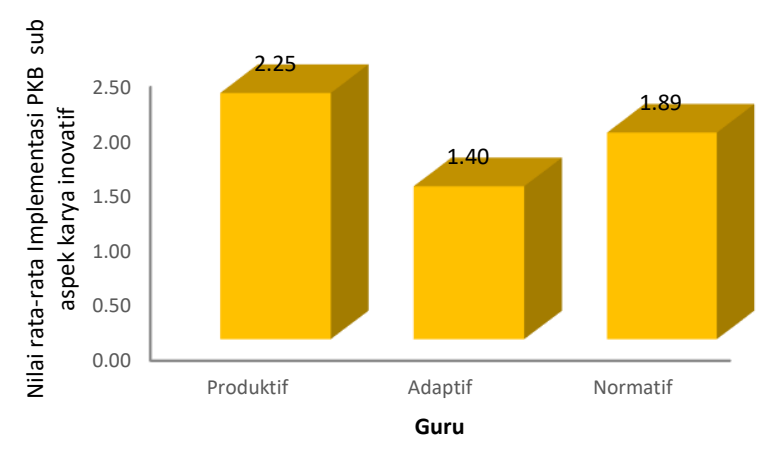

Gambar 4. Grafik Perbandingan Nilai Rata-Rata Implementasi PKB Aspek Karya Inovatif dengan Kelompok Guru (Normatif, Adaptif Dan Produktif) 
Pada aspek karya inovatif guru normatif lebih unggul dibandingkan dengan guru adaptif. Hal tersebut dikarenakan terdapat guru normatif yang rajin untuk membuat/memodifikasi alat peraga dan pernah mengikuti penyusunan standar, pedoman soal dan sejenisnya. Guru adaptif lebih terkesan pasif dalam hal karya inovatif dibandingkan guru produktif dan adaptif. Susanto (2016) menjelaskan bahwa pelaksanaan PKB aspek karya inovatif pada Guru SMK Otomotif di Wilayah Purworejo masih tergolong rendah. Hal tersebut dikarenakan guru tersebut lebih memilih media yang sudah ada di Internet sehingga tidak perlu repot untuk membuat media terlebih dahulu. Ketidaksiapan dan ketidakmampuan guru dalam mengembang-kan bahan ajar. Kemudian keterbatasan waktu, sarpras yang dimiliki.

Karya inovatif khususnya dalam menemukan dan menciptakan karya seni juga tidak jauh berbeda dengan yang lainya. Hal tersebut dikarenakan tidak semua guru atau hanya sebagian kecil guru yang memiliki minat dan bakat dalam bidang seni (Susanto, 2016). Selain itu sebagian besar guru dalam rumpun teknologi beranggapan bahwa seni bukan merupakan pengembangan dari profesionalitas dan hanya dianggap hiburan semata.

\section{SIMPULAN DAN SARAN}

Kesimpulan yang dapat diambil dari Kajian ini adalah (1) persepsi guru SMKN 1 Seyegan Sleman jurusan Teknik Gambar Bangunan (TGB) terhadap prosedur kenaikan pangakat PKB yang diberlakukan pemerintah masuk dalam kategori persepsi baik $(\bar{X}=4,96$, kategori baik $=4,5 \leq \bar{X}<6,75)$. Hal ini dikarenakan sebagian besar guru menyadari bahwa PKB dapat memberikan akibat yang positif bagi kemajuan kompetensi guru dan perkembangan karier guru; (2) keefektifan implementasi PKB aspek Publikasi Ilmiah di SMKN 1 Seyegan Jurusan Teknik Gambar Bangunan (TGB) adalah 12,13 \% (tidak efektif). Hal ini dikarenakan banyak guru yang belum memahami cara dan metode untuk melaksanakan Kajian, menulis karya tulis dan mempublikasikan karya tulis ilmiah; dan (3) keefektifan implementasi PKB aspek Karya Inovatif di SMKN 1 Seyegan Jurusan Teknik Gambar Bangunan (TGB) adalah 22,26\% (tidak efektif). Hal tersebut dikarenakan banyak guru yang belum memahami cara merancang teknologi tepat guna dan cara untuk menilaikannya sehingga dapat memperoleh angka kredit dari hasil karyanya.

\section{DAFTAR RUJUKAN}

Arikunto, S. (2013). Prosedur penelitian: suatu pendekatan praktik. Jakarta: Rineka Cipta.

Day, C. (1999) Developing teachers: The challenges of lifelong learning. Falmer press: Taylor \& Francis, Inc.

Mawardi. (2012). Pengembangan keprofesian berkelanjutan (PKB) dan kewajiban memenuhi jam mengajar kebijakan dilematis. Jurnal scholaria, vol. 2, no. 1, Januari 2012 :91-115.

Peraturan Menteri Negara dan Pendayagunaan Aparatur Negara dan Reformasi Birokrasi Nomor 16 Tahun 2009 Tentang Jabatan Fungsional Guru dan Angka Kreditnya. (2009).

Phillips, P. (2008). Professional development as a critical component of continuing teacher quality. Australian Journal of Teacher Education Vol 33, 1, January 2008.

Ratih, E. (2001). Fungsi tari sebagai seni pertunjukkan. Harmonia Jurnal Pengetahuan dan Pemikiran Seni.Vol.2 No.2 Mei Agustus 2001.

Schostak, J., Davis, M., Hanson, J., Schostak, J., Brown, T., Driscoll, P., Starke, I., dan Jenkins, N. (2010) The effectiveness of continuing professional development., Final report. College of Emergency Medicine 35 Red Lion Square London WC1R 4SG. 
Soeharto, Sukir, dan Nugraha, A.C. (2013) Model pengembangan keprofesian berkelanjutan guru smk program keahlian ketenagalistrikan menggunakan multimedia interaktif berbasis portal elearning. Laporan tahunan Kajian hibah bersaing. Universitas Negeri Yogyakarta.

Sumardjoko, B. (2017). Pemetaan kemampuan guru dalam penulisan karya ilmiah. The 5th Urecol Proceding ISBN 978-9793812-42-7. Yogyakarta.

Susanto, A. (2016). Pelaksanaan pengembangan keprofesian berkelanjutan (PKB) pada guru SMK Teknik Otomotif di Wilayah Purworejo. Makalah disajikan dalam Seminar Nasional Pendidikan. SNP 2016, ISSN:2503-4855.

Syakbaniyah, S.N. (2017). Analisis kesulitan guru bersertifikasi dalam penulisan karya ilmiah kasus pada guru-guru bersertifikasi di SMK Sakti Gemolong. Tesis Magister, Universitas Muhammadiyah Surakarta, Surakarta.

Undang-Undang Republik Indonesia Nomor 14 Tahun 2005 Tentang Guru dan dosen. (2005).

Walter, C. dan Briggs, J. (2012). What professional development makes the most different to teachers? Oxford: Oxford University Press.

Yunanto, E. (2007). Evaluasi program bimbingan teknis penulisan karya ilmiah pengembangan profesi guru sekolah menengah di Propinsi Jawa Tengah. Tesis Magister, Universitas Negeri Semarang, Semarang. 